\title{
Kinerja Jaringan Sensor Nirkabel untuk Model Smart Building
}

\author{
I Made Sastra Dwikiarta ${ }^{1}$, Nyoman Putra Sastra ${ }^{2}$, Dewa Made Wiharta ${ }^{3}$ \\ [Submission: 11-04-2021, Accepted: 27-05-2021]
}

\begin{abstract}
The use of energy in wireless sensor networks today can be said to be very wasteful, so it takes a computational method on Internet of Things (IoT) technology with limited resources. The concept of energy use in IoT needs to be supervised and managed so that there is an increase in energy usage efficiency to reduce costs without having to reduce its performance. In this study, a prototype of energy usage control system in IoT was later used for Smart Building model in energy saving efforts. The prototype concept created is a hybrid network. In the prototype used several sensors serve to read, control, and transmit information in realtime with the zigbee protocol IEEE 802.15.4 and Wi-Fi ESP8266-01. This model observed and analyzed energy consumption and Quality of Service (QoS) transmission of data transmission by clustering method. Performance on the network works well in terms of indoor and outdoor environments. Testing energy consumption throughout the process of sending sensor data that is 0.32 Watts to 0.64 Watts within 10 Minutes, it can be said that network communication in the development of hybrid network consumes very low energy. The total duration of testing time with a battery of 12 Volts up to the minimum voltage limit obtained 70 Minutes and a minimum voltage of up to 7 Volts.
\end{abstract}

Keywords - Internet of Things, Smart Building, Zigbee, Energy consumption

Intisari- Penggunaan energi pada jaringan sensor nirkabel saat ini bisa dikatakan sangat boros, sehingga dibutuhkan sebuah metode komputasi pada teknologi Internet of Things (IoT) dengan sumber yang terbatas. Konsep penggunaan energi pada IoT perlu diawasi dan dikelola supaya terdapat peningkatan efisensi penggunaan energi sehingga dapat menekan biaya tanpa harus mengurangi kinerjanya. Dalam penelitian ini dibuatlah sebuah prototype sistem kontrol penggunaan energi pada IoT yang nantinya digunakan untuk model Smart Building dalam upaya penghematan energi. Konsep prototipe yang dibuat adalah hybrid network. Pada prototipe digunakan beberapa sensor berfungsi untuk membaca, mengontrol, dan mengirimkan informasi secara realtime dengan protokol zigbee IEEE 802.15.4 dan Wi-Fi ESP8266-01. Model ini diamati dan dianalisis konsumsi energi dan Quality of Service (QoS) transmisi pengiriman data dengan metode clustering. Kinerja pada jaringan bekerja dengan baik dilihat dari kondisi pada lingkungan indoor maupun outdoor. Pengujian konsumsi energi seluruh proses pengiriman data sensor yaitu 0.32 Watt sampai dengan 0.64 Watt dalam waktu 10 Menit, dapat dikatakan komunikasi jaringan pada pengembangan hybrid network ini mengonsumsi energi yang sangat rendah. Total durasi waktu pengujian dengan baterai 12 Volt hingga batas tegangan

${ }^{1}$ Mahasiswa, Magister Teknik Elektro Universitas Udayana, Gedung Pascasarjana Universitas Udayana Jl. PB Sudirman Denpasar-Bali, Kode Pos: 80232; (tlp/fax: 0361-239599; e-mail sastradwikiarta@gmail.com

2,3 Dosen, Magister Teknik Elektro Universitas Udayana, Gedung Pascasarjana Universitas Udayana Jl. PB Sudirman Denpasar-Bali, Kode Pos: 80232; (tlp/fax: 0361-239599; e-mail 22putra.sastra@unud.ac.id, ${ }^{3}$ wiharta@unud.ac.id

I Made Sastra Dwikiarta: Kinerja Jaringan Sensor Nirkabel ... minimum didapatkan 70 Menit dan tegangan minimal mencapai 7 Volt.

Kata Kunci- Internet of Things, Smart Building, Zigbee, Konsumsi energi

\section{PENDAHULUAN}

Internet of Things (IoT) adalah suatu konsep yang memiliki kemampuan untuk mengirimkan data secara terus menerus melalui jaringan internet. Smart Building merupakan contoh implementasi Internet of Things (IoT). Konsep dari Smart Building menyatukan beberapa desain yaitu: arsitektur, interior dan mekanikal elektrikal untuk memudahkan akses kontrol dan akses building [1][2][3].

Pengelolaan Smart Building dimasa yang akan datang tentunya akan menjadi salah satu unsur dalam pengembangan dari Smart City. Pengelolaan energi, sebagai salah satu unsur dalam Smart Building, meperhatikan beberapa faktor, salah satunya kenyamanan dan integrasi dengan layanan terkait, seperti aplikasi mobile ataupun berupa dashboard untuk melakukan monitoring [4]. Pengaruh faktor tersebut akan berdampak pada penghematan energi. Platform dasar dari Internet of Things (IoT) adalah Jaringan Sensor Nirkabel (JSN).

JSN merupakan sekumpulan sensor yang dapat mamantau kondisi fisik lingkungannya ataupun mengumpulkan data. Sensor akan saling terbubung antara sata dengan yang lainnya secara realtime[5].

Telah banyak penelitian terkait dengan Smart Building, sebagai contoh penelitian mengenai prototype Lampu Penerangan Jalan di lingkungan JSN yang befokus pada penghematan energi [6][7][8]. Penelitian lain adalah di bidang tata udara, monitoring suhu ruangan dilakukan dengan dengan menggunakan Zigbee, dengan mengirimkan data suhu dilakukan secara realtime [9]. Komunikasi data yang digunakan adalah Modul Xbee series1 dengan protokol Zigbee IEEE 802.15.4. Sebagai pendukung metode pada peneltian artikel ini melakukan penelitian monitoring reservoir air dibeberapa gedung dari jarak jauh. Penelitian masih dalam bentuk prototype menggunakan modul Wi-fi dengan konsep JSN[10]. Arduino Uno sebagai perangkat keras untuk mengolah data sensor, yaitu Ultrasonik HCSR04 berfungsi untuk untuk membaca ketinggian air ditempat penampunganya. Perancangan dan percobaan hasil penelitian visualisasikan dalam bentuk grafik. Gambar tiruan reservoir air ditampilkan dalam halaman web yang telah dibuat dan data dapat disimpan ke dalam database. Protokol yang digunakan adalah Zigbee dengan hardware Xbee S2. Penelitian lain membahas QoS dan Konsumsi Energi. Proses transmisi data menggunakan modul Xbee IEEE 802.15.4 pada Data Center dengan membuat prototype sebagai alat uji [11][12][13]. Untuk memperpanjang kemampuan komunikasi protokol Zigbee IEEE 802.15.4

$$
\text { p-ISSN:1693 - 2951; e-ISSN: 2503-2372 }
$$


dikembangkan Hybrid Network dengan mencari QoS dan Konsumsi Energi dari proses transmisi data [14].

Salah satu infrastruktur IoT saat ini adalah Jaringan Sensor Nirkabel (JSN), yaitu infrastruktur dengan kemampuan untuk pengembangan aplikasi yang memanfaatkan hasil tangkapan sensor sebagai sumber data. Karakteristik JSN terutama pada pemanfaatan resource terbatas, yaitu processing, komunikasi, dan energi yang terbatas [15]. Untuk mendapatkan kualitas yang baik dalam proses pengiriman data, dengan kondisi trafik data relatif besar dengan konsumsi energi sangat rendah maka Quality of Service (QoS) merupakan syarat mutlak. Dalam [16], penelitian ini menggunakan Wireless Sensor Networks berbasis teknologi ZigBee, bertujuan untuk mengetahui kinerja jaringan dari teknologi ZigBee. Parameter yang diuji yaitu delay, throughput, packet loss, dan RSSI.

Berdasarkan referensi-referensi di atas, maka penelitian ini mengajukan sebuah konsep pengembangan prototype hybrid network yang dimana sebelumnya belum ada penelitian yang menggabungkan 2 komunikasi jaringan Zigbee dengan Wifi konsep Smart Building serta menguji kinerja jaringannya, yang
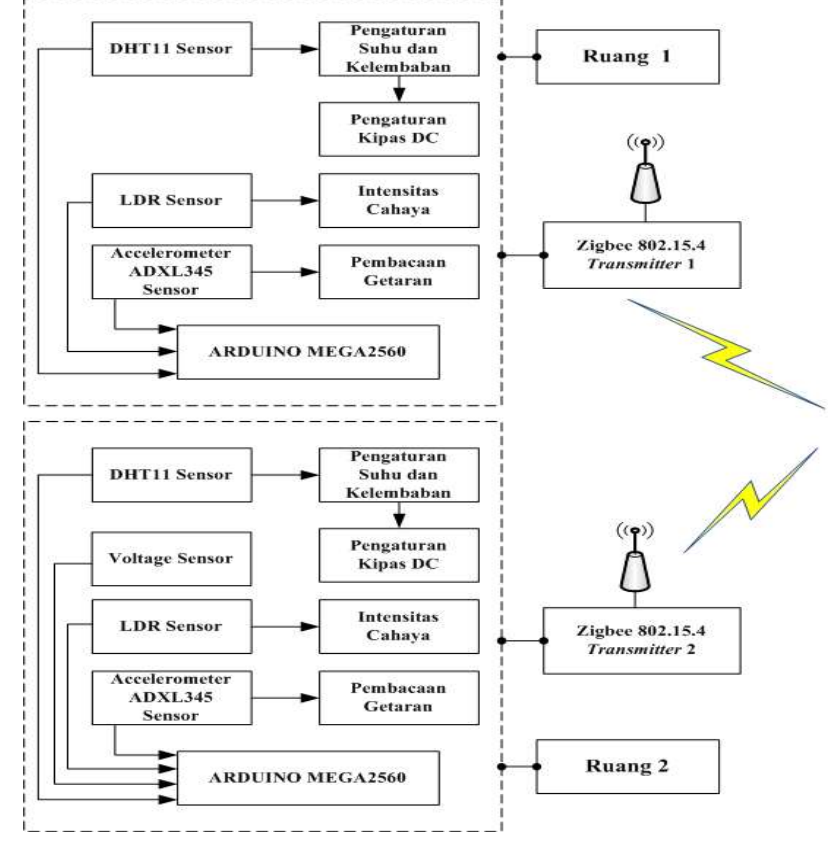

Gambar 1: Diagram Blok Prototype menggunakan beberapa node sensor yaitu, suhu, kelembaban, intensitas cahaya, dan tegangan. Khusus pada suhu, sistem didesain untuk dapat melakukan kontrol sehingga suhu yang diinginkan tetap terjaga. Pada model ini akan diamati dan dianalisis konsumsi energi dan Quality of Service (QoS) transmisi pengiriman data, berupa packet loss, and dan delay dengan metode clustering. Hasilnya diharapkan menjadi acuan untuk pengembangan sistem smart building yang hemat sumber daya (resource). Sistem desain, hasil dan analisis serta kesimpulan akan diuraikan pada berikut ini.

\section{SISTEM DESAIN}

Gambar 1: menampilkan desain sistem. Ruang 1 dan Ruang 2 berfungsi sebagai pengumpul data sensor. Sensor node pada Ruang 1 bertugas untuk mengambil data yaitu sensor suhu, kelembaban, intensitas cahaya, getaran, dan tegangan. Sedangkan sensor node pada Ruang 2 bertugas untuk mengambil data sensor suhu, kelembaban, intensitas cahaya, getaran, dan tegangan.
Dari bagian Zigbee Receiver Gambar 1 membedakan data yang diterima dari Zigbee Trasmitter Ruang 1 dan Zigbee Trasmitter Ruang 2. Komunikasi yang digunakan yaitu Wireless Xbee Series 1, dengan protokol Zigbee IEEE 802.15.4. Hasil dari data yang diterima ditampilkan dalam bentuk GUI. Agar data sensor dapat didiseminasikan pada jaringan internet, maka diperlukan interkoneksi antara standard IEEE 802.15.4 dengan IEEE 802.11. Dengan demikian data ini dapat terkirim ke sebuah web Server yang menggunakan protokol TCP/IP. Untuk membedakan data dari sensor dan node yang berbeda, maka setiap data yang dikirim akan diberi tambahan header sebagai identitas sensor.

Gambar 2: merupakan alur data mulai dikirim sampai data diterima di Web thingspeak.com. Dimulai dari sensor mengambil data, kemudian data tesebut diproses oleh Arduino untuk diteruskan melalui perangkat ZigBee dan kemudian ke

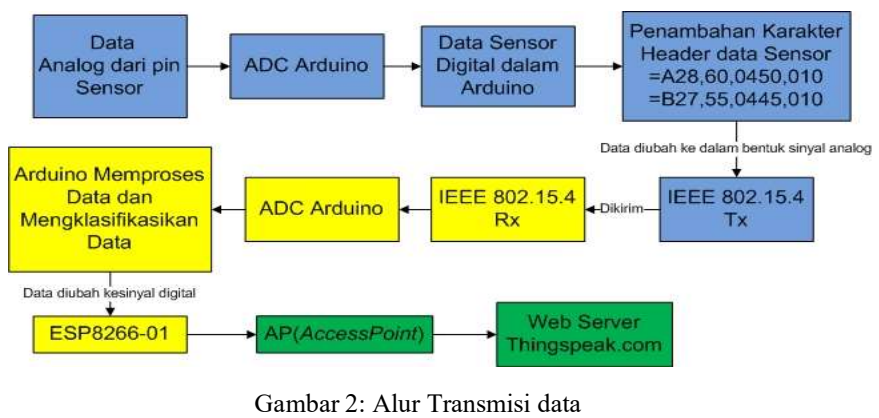

internet melalui modul ESP8266 yang terhubung dengan sebuah Access Point. 
Majalah Ilmiah Teknologi Elektro, Vol. 20, No.2, Juli-Desember 2021

DOI: https://doi.org/10.24843/MITE.2021.v20i02.P05

A. Wireless Sensor Network (WSN)

Wireless Sensor Network terdiri dari beberapa sensor node yang bersifat mandiri yang diletakkan di tempat yang berbedabeda sesuai dengan kebutuhan. Arsitektur WSN dapat dilihat pada Gambar 3: Node-node tersebar di suatu area tertentu dan pada umumnya berukuran kecil. Node tersebut mempunyai kemampuan untuk melakukan route data yang dikumpulkan ke node lain yang berdekatan. Proses pengiriman data dilakukan melalui komunikasi radio nantinya akan diarahkan ke Base Station (BS) atau dengan istilah lain sink node. Sink node berupa perantara node sensor dengan user. Informasi data yang didapat bisa diakses melalui koneksi jaringan internet, ataupun juga satelit. Hal ini memungkinkan user dapat mengakses secara real time[17].

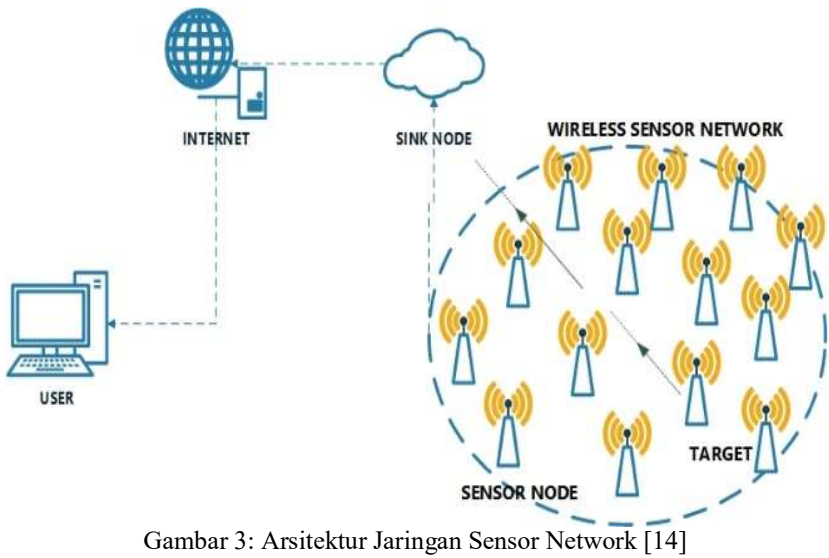

B. Xbee

Spesifikasi dari Modul Xbee ini bekerja pada standard protokol IEEE 802.15.4 dengan frekuensi: $2.4 \mathrm{GHz}$. Modul wireless ini pada data sheet bekerja pada tegangan DC maksimal: $3.3 \mathrm{~V}$ dan arus $50 \mathrm{~mA}$. Receiver Sensitivity (RS): -92 dBm dengan cakupan jarak maksimal pada kondisi di dalam ruangan 30 meter dan kondisi luar ruangan 90 meter. Pin Input dan Output yang dipergunakan dalam modul Xbee Series hanya 6 pin, diantaranya: VCC, GND, RESET, $D_{\text {OUT }}, D_{\text {IN }}$, dan PWMO/RSSI [18][19]. Bentuk fisik dari modul Xbee pada Gambar 4:

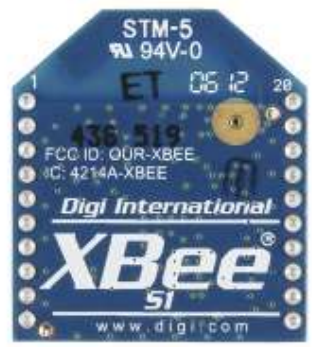

Gambar 4: Modul Wireless XBee-Series

Gambar 5: merupakan ilustrasi dari prinsip kerja dari modul Xbee dimana pin $\mathrm{T}_{\mathrm{X}}$ dan $\mathrm{R}_{\mathrm{X}}$ dan pin $\mathrm{D}_{\mathrm{IN}}$ dan $\mathrm{D}_{\text {OUT }}$ pada modul I Made Sastra Dwikiarta: Kinerja Jaringan Sensor Nirkabel ...

Xbee dihubungkan secara langsung, yang nantinya disimpan terlebih dahulu di $\mathrm{D}_{\mathrm{IN}}$ Buffer dan Radio Frekuensi Tx Buffer sebelum ditransmisikan ke Xbee yang lainnya.

CMOS Logic $(2.8-3.4 \mathrm{~V})$

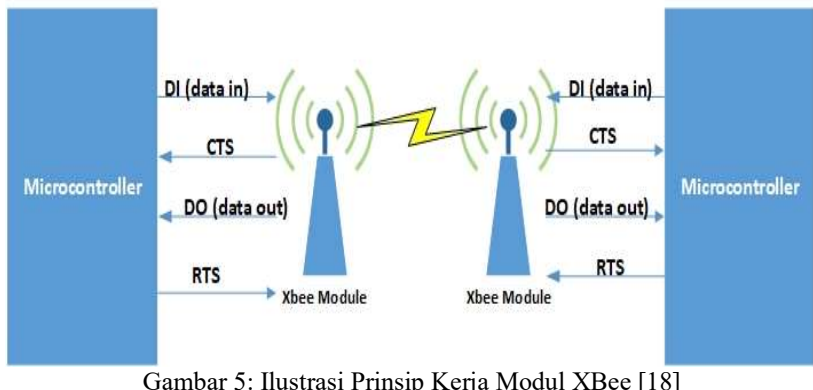

C. Arduino Mega2560

Arduino Mega2560 menggunakan mikrokontroller ATmega2560. Arduino Mega2560 Gambar 6: memiliki spesifikasi sebagai berikut: mempunyai 54 pin digital I/O (Input dan Output), kristal/Clock 16Mhz, socket power DC 12 Volt, pin analog ada 16 pin, pin PWM ada 15 , pin UART 15 , socket USB 5 Volt sebagai port compile koding, dan tombol Reset [20].

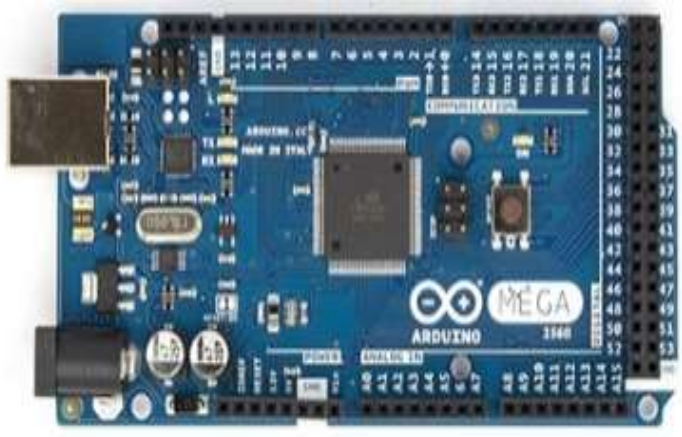

Gambar 6: Arduino Mega2560 [20]

\section{Modul Wi-Fi (IEEE 802.11)}

Modul Wi-Fi merupakan sebuah hardware yang digunakan untuk meneruskan data ke jaringan internet secara wireless. Produk modul Wi-Fi ini memiliki beberapa protokol dalam produksinya di dunia yaitu: 802.11a, 802.11b, 802.11g, 802.11n. Versi modul Wi-Fi bekerja pada frekuansi $2.4 \mathrm{GHz}$. Modul Wi-Fi ini memiliki 11 channel bekerja pada frekuensi 5 GHz. Modul Wi-Fi memiliki beberapa versi, salah satunya modul ESP8266-01 merupakan sebuah hardware yang mempunyai kemampuan proses dalam suatu board dan penyimpanan data yang dapat dikoneksikan dengan modul sensor ataupun aplikasi melalui pin yang dimiliki yaitu pin I/O (input dan output). Tegangan maksimal pada modul yaitu 3.3 Volt DC dengan arus mencapai 80mA. Jarak jangkuan

p-ISSN:1693 - 2951; e-ISSN: 2503-2372 
dari modul ini bisa mencapai maksimal 100 meter. Gambar 7: merupakan Wi-Fi ESP8266-01 [21].

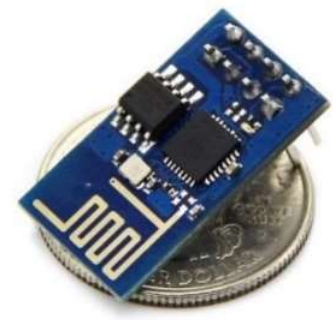

Gambar 7: Fisik modul Wi-Fi ESP8266-01

\section{E. Parameter Kinerja Jaringan Zigbee}

Penetapan parameter protocol Zigbee bertujuan untuk mengetahui kinerja jaringan transmisi data yang dikirmkan atau diterima. Parameter yang ditetapkan untuk mengetahui kualitas jaringan ada 3 yaitu: 1). Throughput, adalah bandwidth yang sudah terukur dalam satuan waktu contohnya dalam mendownload sebuat data/file, 2). Delay adalah keterlambatan waktu dalam mentransimisikan data dari pengirim ke penerima, dan 3). Media Access Delay yaitu total dari delay dalam pengiriman data yang disebabkan oleh buffer dan contention. Media Access Delay diukur tiap paket data yang dikirim ketika paket dikirimkan ke physical layer pada waktu tertentu, hal itu dapat mengakibatkan packet loss. [22]

\section{F. Konsumsi Daya}

Daya merupakan sumber utama yang digunakan pada semua perangkat keras. Dalam seluruh peralatan elektronik penggunakaan konsumsi daya dapat dilihat dari berapa beban/arus (A) yang masuk dan tegangan (V) pada peralatan elektronik tersebut. Jumlah penggunaan daya dapat dinyatakan dalam rumus 1 .

$$
\text { Daya }(W)=\operatorname{Arus}(A) \times \text { Tegangan }(\text { Volt })
$$

\section{G. Software X-CTU}

Software X-CTU sebuah perangkat lunak yang digunakan untuk mengonfigurasi dan menguji XBee. Pemberian alamat dari XBee dapat dilakukan dengan Software X-CTU. Selain itu, dapat mengonfigurasi XBee menjadi master ataupun menjadi slave. Software X-CTU mendukung untuk pengaturan XBee Series maupun XBee-PRO. Dengan mengatur konfigurasi XBee maka modul Zigbee 802.15.4 sudah siap digunakan untuk melakukan pengiriman data point to point atau point to multipoint dengan baud rate 9600 bps [23].

Parameter ditunjukkan pada Gambar 8: yang diatur agar kedua Zigbee 802.15.4 dapat berkomunikasi dalam pengiriman data dan penerimaan data adalah sebagai berikut, (Personal Area Network Identity) PAN ID merupakan identitas pengenal yang berkomunikasi dengan perangkat Zigbee 802.15.4 (intrapersonal komunikasi) dalam satu jaringan. Parameter (Destination Address Low) DL merupakan sebuah parameter penerima data yang didefinisikan pada Zigbee 802.15.4.
Parameter (Source Address) MY merupakan sebuah parameter pengiriman data yang didefinisikan pada Zigbee 802.15.4.

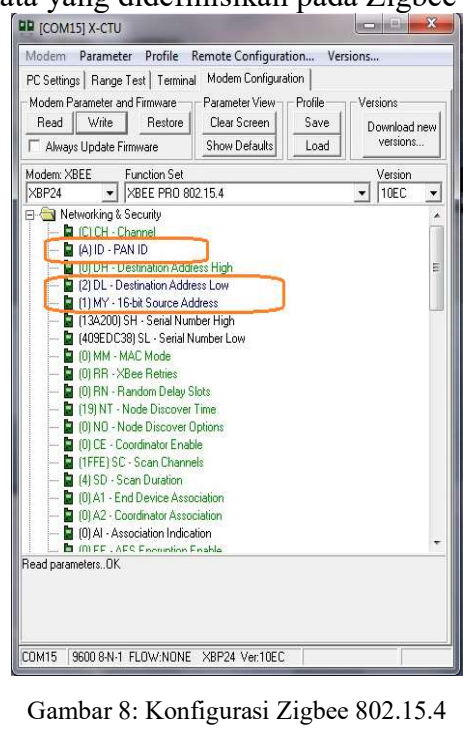

\section{H. Hybrid Network}

Hybrid Network merupakan jaringan berbasis client-server yang terbentuk dari beberapa topologi, dalam hal ini digabung dari beberapa teknologi yang berbeda. Contohnya dalam penelitian ini menggabungkan protokol zigbee IEEE 802.15.4 dan Wi-Fi ESP8266-01 secara peer to peer.

\section{HASIL DAN ANALISIS}

\section{A. Realisasi Hasil Perancangan Desain Hybrid Network}

Realisasi hasil perancangan Desain Hybrid Network tampak atas dapat dilihat pada Gambar 9: dan Gambar 10:

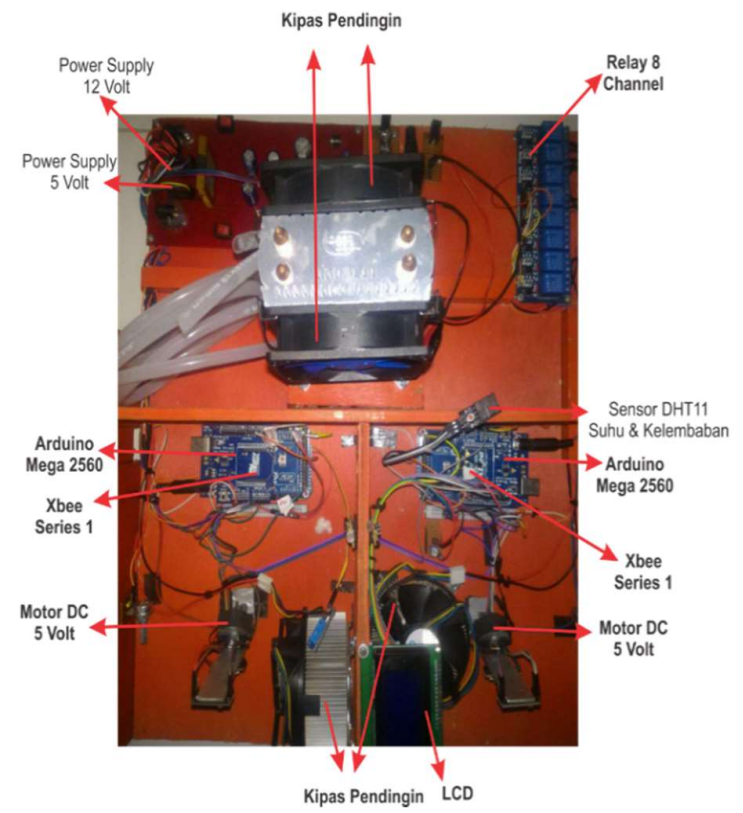

Gambar 9: Realisasi Node Sensor Transmitter Zigbee Ruang 1 dan Ruang 2 


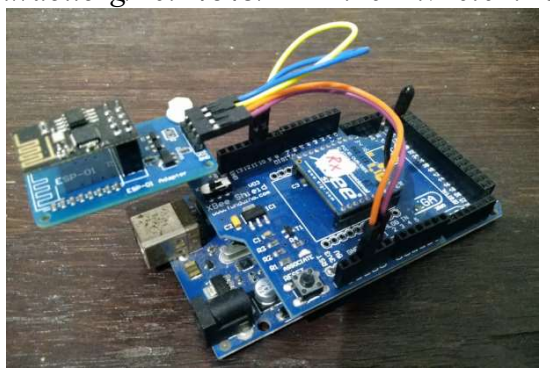

Gambar 10: Realisasi Hybrid Network Komunikasi Zigbee Receiver dan Modul Wi-Fi ESP 8266-01

Tabel 1 merupakan spesifikasi dari prototype yang digunakan dalam penelitian, sebagai berikut;

TABEL 1

SPESIFIKASI PROTOTYPE HYBRID NETWORK

\begin{tabular}{|l|l|}
\hline Spesifikasi & Prototype Smart Building \\
\hline Baterai & Lipo polimer 2200mAh 12volt dan 1000mAh 11.1 Volt \\
\hline Mikrokontroler & Arduino Mega 2560 \\
\hline Sensor & DHT11, LDR, ADXL345, Tegangan \\
\hline Komunikasi & Zigbee 802.15.4 Series 1 dan ESP8266 \\
\hline Pendingin & Peltier \\
\hline Penggerak & Motor DC 5Volt, Kipas DC 12Volt \\
\hline Penerangan & LED 1 Watt \\
\hline Kontrol & Relay 8 Channel \\
\hline
\end{tabular}

B. Pengujian Jarak Jangkauan Komunikasi Zigbee 802.15.4 (Outdoor)

Pengujian pengiriman data sensor dari Zigbee Pengirim, Tx, ke Zigbee Penerima, Rx, bertujuan melihat kemampuan Zigbee dalam melakukan pengiriman dan penerimaan data jarak tertentu dengan software X-CTU. Tabel 2 merupakan hasil pengukuran Receive Signal Strength Indicator (RSSI) pada komunikasi Zigbee di kondisi outdoor dan Gambar 11: merupakan visualisasinya dalam bentuk grafik.

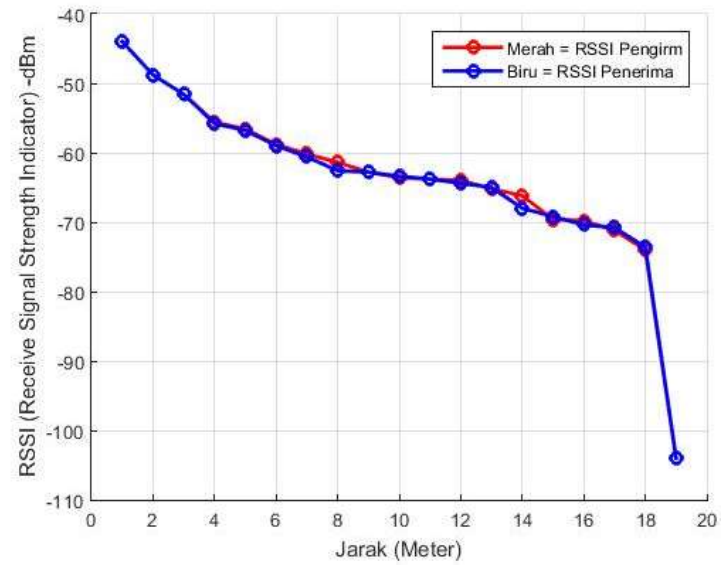

Gambar 11: Grafik Hasil Pengukuran Jarak Komunikasi Zigbee (outdoor)

I Made Sastra Dwikiarta: Kinerja Jaringan Sensor Nirkabel ...
Hasil dari pengujian jarak komunikasi Zigbee dapat mengirimkan data dengan maksimal jarak 19 meter, yang artinya pada pengujian menggunakan software X-CTU tidak menerima data yang dikirimkan. Dapat dilihat pada dan Gambar 11 ada 2 line merah (RSSI Pengirim) dan biru (RSSI Penerima), dengan Receiver Sensitivity pada jarak awal adalah -44 dBm sedangkan dengan jarak terjauh, yaitu maskimal 19 meter, nilai RSSInya adalah $-104 \mathrm{dbm}$. Semakin jauh pengujian jarak komunikasi Zigbee, maka kuat sinyal akan semakin rendah dan komunikasi terputus. C. Pengujian Jarak Jangkauan Komunikasi Zigbee 802.15.4
(Indoor)

Pengujuan jangkauan jarak juga dilakukan dalam ruangan tertutup Indoor bertujuan sebagai pembanding lingkungan Outdoor. Dalam pengujian digunakan software X-CTU. Tabel 3 merupakan hasil pengukuran Receive Signal Strength Indicator (RSSI) pada komunikasi Zigbee di kondisi outdoor dan Gambar 12: merupakan visualisasinya dalam bentuk grafik.

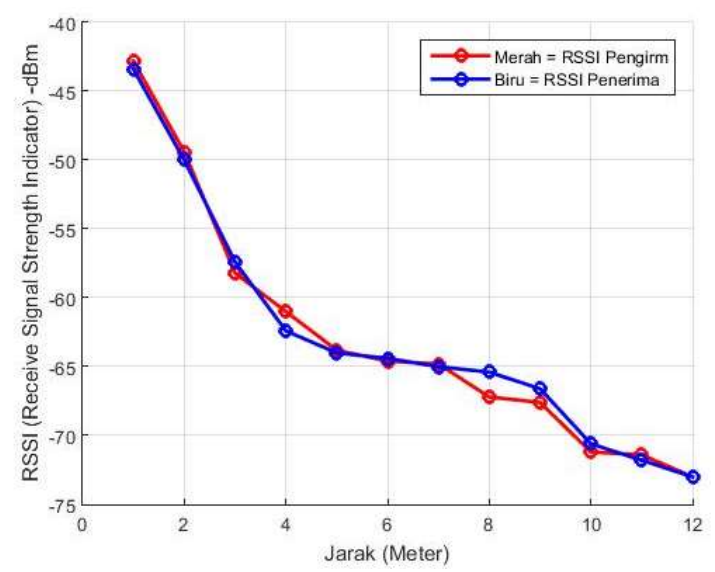

Gambar 12: Grafik Hasil Pengukuran Jarak Komunikasi Zigbee (indoor)

Jarak komunikasi maksimum untuk pengujian jarak Zigbee di lingkungan indoor adalah 12 meter, karena keterbatasan luas ruangan pada pengujian. Perubahan nilai RSSI pada kondisi indoor tidak terlalu signifikan di setiap jarak pengukuran. Hasil yang didapatkan di lingkungan indoor tidak jauh berbeda, dengan kondisi outdoor, semakin jauh jarak komunikasi Zigbee kuat sinyal akan semakin menurun. Untuk komunikasi indoor banyak dipengaruhi oleh beberapa kendala salah satunya distorsi sinyal, kehilangan data dan multipath fading.

\section{Analisis QoS dalam Transmisi data}

Pada masing-masing pengujian dilakukan perubahan jarak perangkat Zigbee Tx yang berfungsi untuk mengirimkan data dari Ruang 1 dan 2 antara perangkat hybrid Zigbee Receiver. Dengan perubahan 2 parameter jarak Tx-Rx dan jumlah data sensor yang dikirim akan diamati QoS jaringannya. QoS yang dianalisis adalah delay dan packet loss selama transmisi data. Sedangkan, untuk menganalisis konsumsi daya, pengujian dilakukan dengan mengatur jarak antar ZigBee Transmitter p-ISSN:1693 - 2951; e-ISSN: 2503-2372 
dengan ZigBeee Receiver. Sebelum melakukan pengujian perlu diketuhui beberapa faktor salah satunya faktor interferensi sinyal.

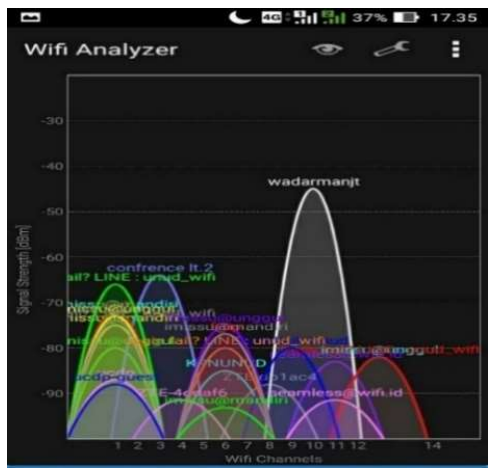

Gambar 13: Tampilan WiFi Analyser di sekitar pengujian

Gambar 13: menunjukkan bahwa di daerah pengujian terdapat banyak Wi-Fi yang sudah terpasang dan jenis wireless yang bekerja pada frekuensi 2.4 Ghz. Dengan banyaknya penggunaan frekuensi $2.4 \mathrm{Ghz}$ dapat menyebabkan adanya gangguan/interferensi. Faktor channel yang digunakan saling timpang tindih, sehingga channel yang tersedia sudah digunakan oleh Wi-Fi tetangga. Jadi kepadatan sinyal itulah yang dapat menyebabkan adanya interferensi, pengaruh yang diberikan oleh interferensi mengakibatkan sinyal data yang diterima serta trafik data yang dilewatkan tidak sesuai. Hal ini dapat mengakibatkan packet loss. Sehingga untuk megoptimasi jaringan menjadi lebih baik diperlukan solusi yaitu memindahkan atau memilih channel yang tepat dan migrasi frekuensi yang berbeda, namun sesuai ketentuan yang berlaku. Dalam penelitian ini menggunakan ZigBee dengan Frekuensi 2.4 Ghz dan menggunakan channel 1, hal ini akan menyebabkan terjadinya interferensi karena berdasarkan Wi-Fi analyser, ada beberapa perangkat wireles menggunakan channel tersebut.

\section{E. Pengujian Delay Terhadap Jarak}

Berikut adalah hasil dari pengujian delay terhadap jarak komunikasi Zigbee ini didapatkan hasil pada Gambar 14: merupakan visualisasi dalam bentuk grafik.

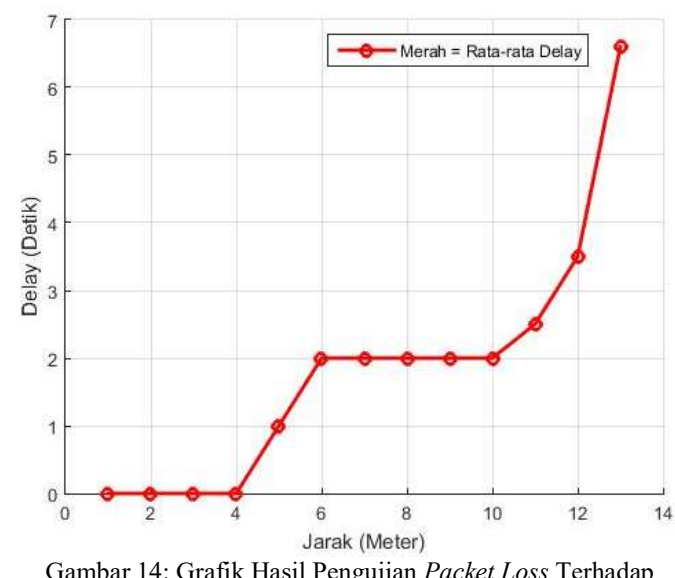
Jarak Komunikasi Zigbee
Pada pengujian ini, delay didapatkan dari jeda sebuah data yang diterima terhadap data yang dikirim sebelumnya. Pada pengujian delay terhadap jarak, dilakukan pengujian pada setiap perubahan satu meter untuk lokasi di luar ruangan/Outdoor. Hal ini dilakukan untuk mengetahui apakah panjang jarak dapat memengaruhi besarnya delay atau tidak. Dari hasil pengujian, didapat bahwa jarak berbanding lurus dengan delay, yang artinya semakin jauh jarak komunikasi Zigbee maka delay yang didapatkan juga semakin besar. Hal ini dapat terjadi ketika jarak yang dikirim lebih jauh, maka waktu pengiriman dibutuhkan lebih lama, selain itu gangguan (interferensi) dari luar sistem juga dapat menyebabkan delay menjadi semakin besar yang dapat memengaruhi proses pengirman data.

\section{F. Pengujian Packet Loss Terhadap Jarak}

Pengujian Packet Loss terhadap jarak Zigbee dilakukan pada lokasi Outdoor halaman Kampus Teknik Elektro Bukit Jimbaran, dengan jarak yang digunakan sesuai dengan pengujian jarak jangkaun Zigbee yaitu 13 meter. Hasil pengujian dapat dilihat pada Gambar 15: visualisasi dalam bentuk grafik.

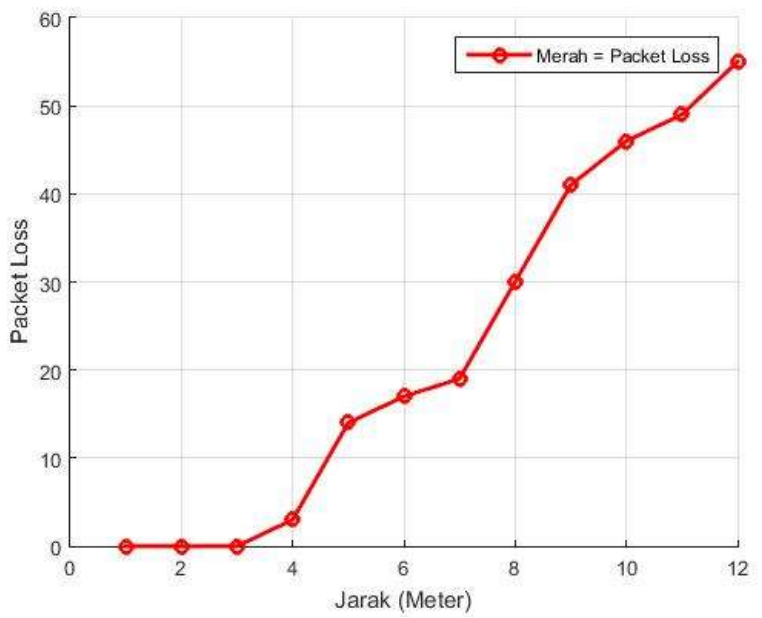

Gambar 15: Grafik Hasil Pengujian Packet Loss Terhadap Jarak Komunikasi Zigbee

Dari sistem yang dibuat, pada proses pengiriman data sensor, untuk membedakan kedua ruangan maka diberikan penanda berupa header terhadap paket yang dikirimkan. Risiko packet loss pada data sensor adalah semua paket data hilang, hal ini akan merugikan pihak user dalam mendapatkan informasi data sensor yang dikirim.

\section{G. Pengujian Penggunaan Konsumsi Daya Terhadap Jarak}

Pengujian dilakukan dengan menggunakan baterai LiPo 12 volt, 2200mAh, 35C dan .LiPo 12 volt, 1000mAh, 30C. Dengan waktu pengujian 10 Menit dengan jarak yang diubahubah, agar terlihat perubahan pengujian konsumsi daya terhadap jarak. 


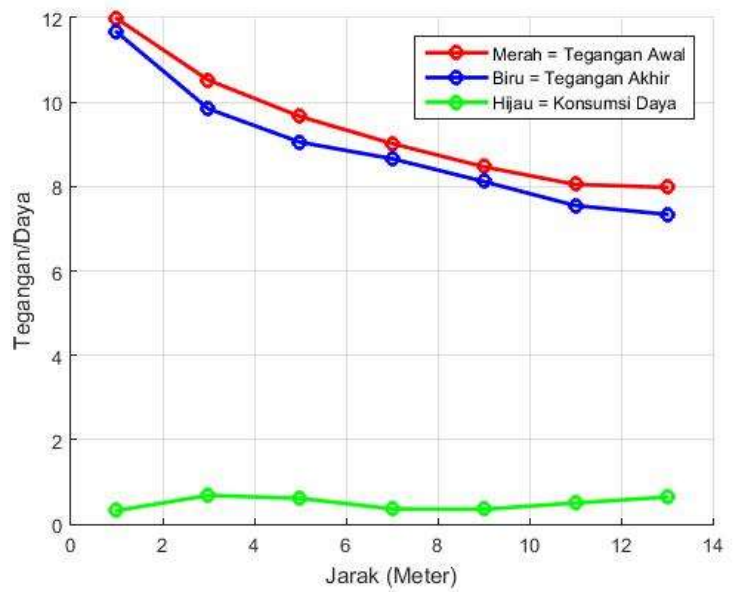

Gambar 16: merupakan grafik konsumsi daya yang diukur dari 10 menit dalam pengiriman data sensor. Konsumsi daya yang digunakan 0.32 Watt sampai dengan 0.64 Watt. Daya bertambah seiring bertambahnya jarak antara pengirim dan penerima. Semua data konsumsi daya yang didapat dalam durasi penelitian selama 10 menit di bawah 1 Watt. Jadi total durasi waktu jika prototype digunakan secara terus menerus hingga batas tegangan manimum dengan jarak diubah ubah didapatkan \pm 70 menit dan tegangan minimal mencapai \pm 7 Volt kondisi prototype berhenti total pada pengujian. Dapat dikatakan komunikasi Zigbee mengonsumsi daya yang relatif rendah. Semakin jauh jarak dalam pengiriman/transmisi data, semakin besar pula konsumsi dayanya.

H. Pengujian Pengiriman Data Sensor ke GUI (Offline Mode) Gambar 17: menunjukkan hasil perancangan software Prototype Smart Building.

Gambar 16: Grafik Hasil Pengujian Penggunaan Konsumsi DayaTerhadap Jarak

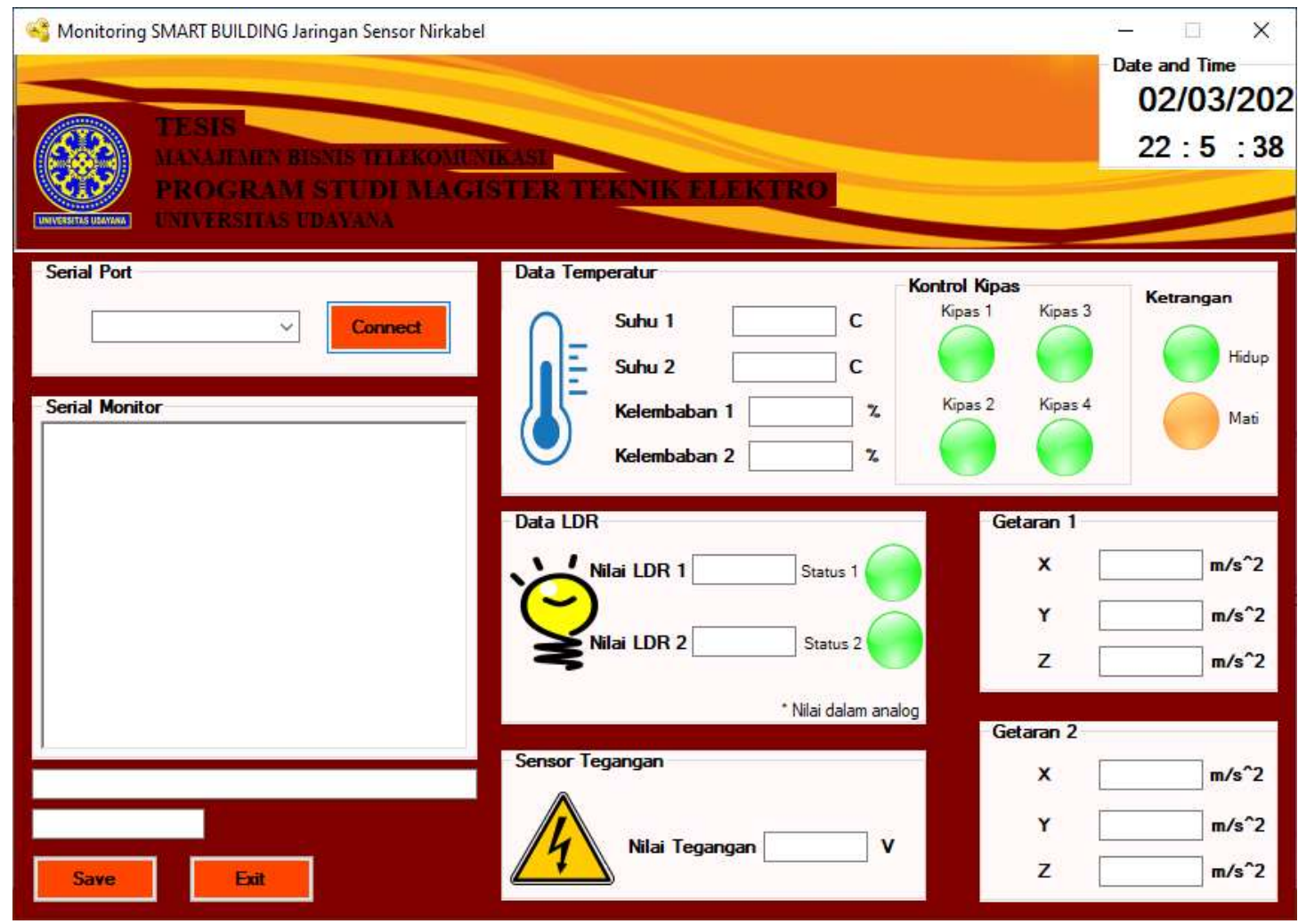

Gambar 17: Hasil Realisasi Perangkat Lunak

Pengujian pengiriman informasi nilai sensor ke GUI bertujuan untuk mengetahui data yang dikirimkan oleh prototype sudah sampai dan bisa di terjemahkan di GUI. Beberapa data yang dikirimkan oleh prototype ke GUI akan digunakan sebagai parameter untuk memvisualisasi kondisi suhu ruangan, kelembaban ruangan, intensitas cahaya, dan tegangan. Hasil pengujian yang telah dilakukan ditunjukkan pada Gambar 18: 


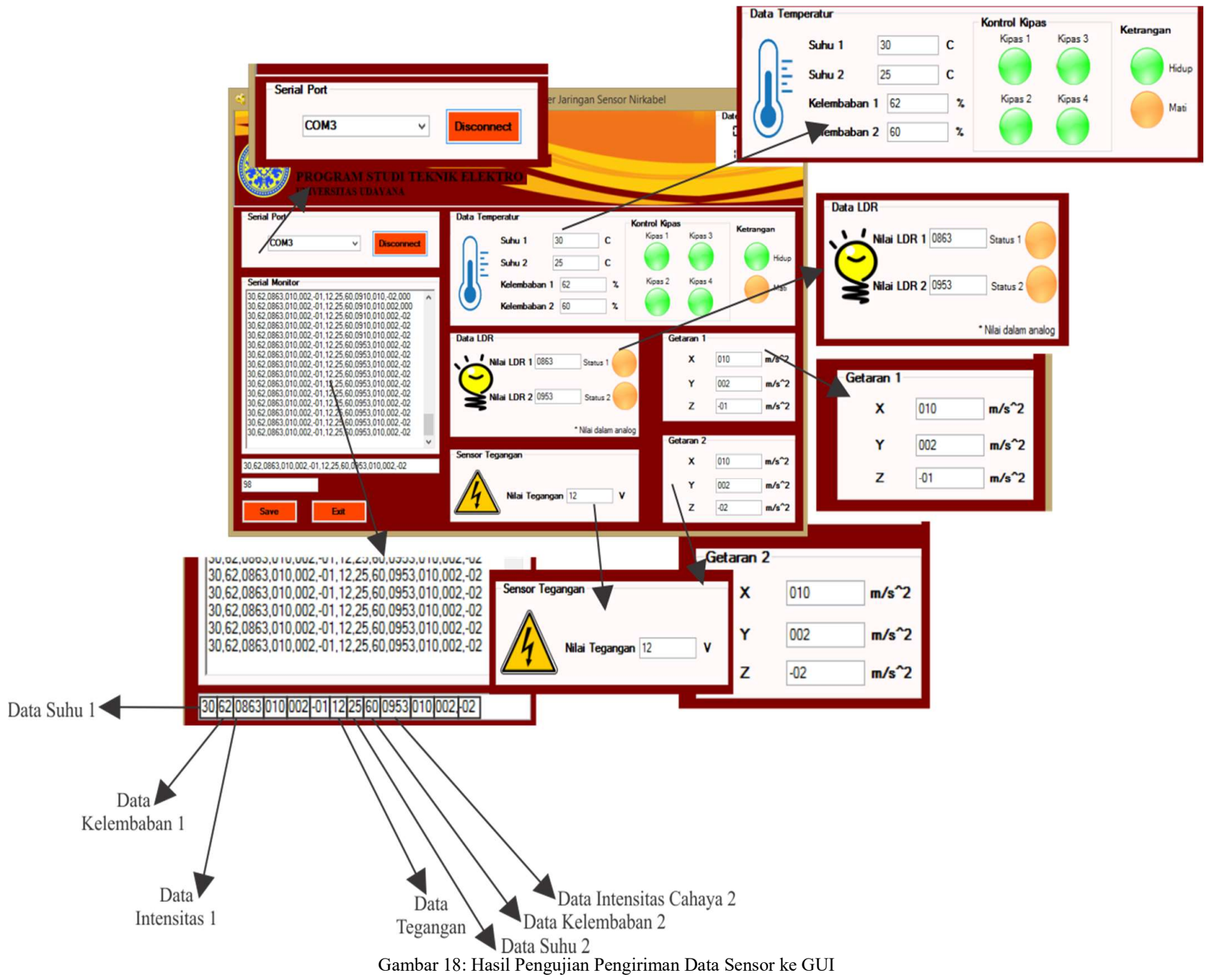

Dari Gambar 18: satu baris data dalam bentuk string akan di parsing (dipilah-pilah) sesuai dengan alamat data masingmasing. Dari hasil pengujian tersebut, menandakan bahwa data informasi nilai sensor sudah sampai dan dapat diterjemahkan oleh GUI sesuai dengan informasi yang dibutuhkan.

I. Pengujian Komunikasi Zigbee 802.15.4 ke ESP8266 IEEE 802.11 (Hybrid Network)
Tahap ini bertujuan mengirimkan data ke Web Server thingspeak.com melalui koneksi internet. Data yang dikirimkan ke Web thingspeak.com disesuaikan dengan APIKEY atau kode keamanan akun channel yang didaftarkan. Setiap channel memiliki field untuk menempatkan data yang yang dikirim oleh sensor. Karena setiap channel hanya memiliki 8 field, maka jumlah maksimal data sensor yang dikirimkan adalah 8 . 
Majalah Ilmiah Teknologi Elektro, Vol. 20, No.2, Juli-Desember 2021

DOI: https://doi.org/10.24843/MITE.2021.v20i02.P05

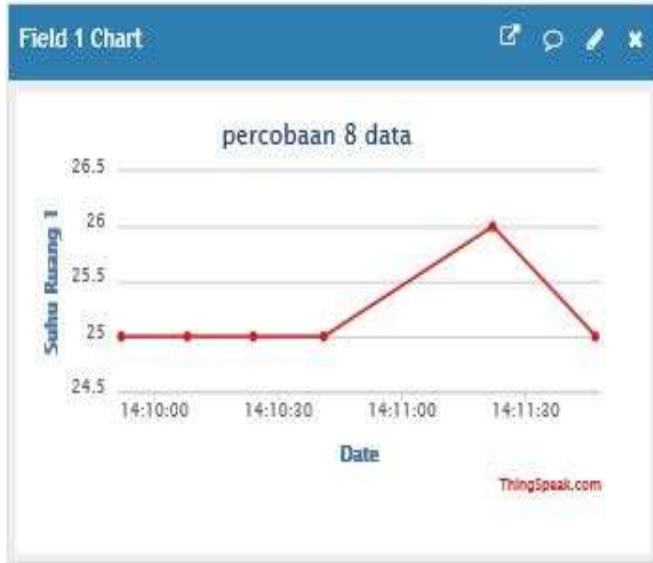

Field 3 Chart

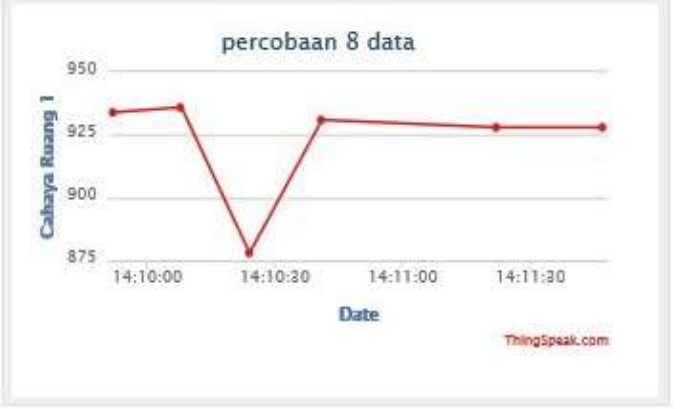

\section{Field 2 chart}

ए $p x$

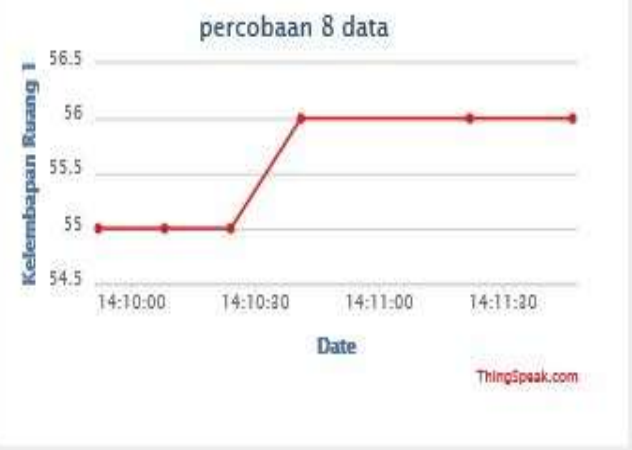

Field 4 Chart

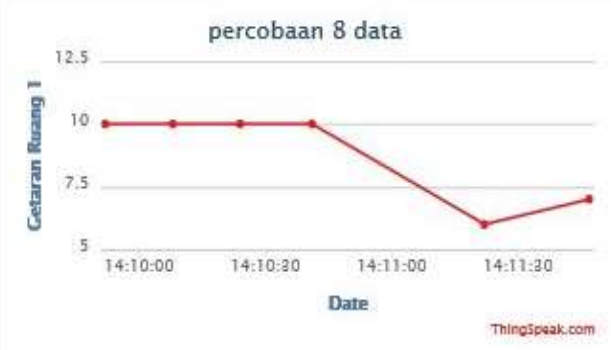

I Made Sastra Dwikiarta: Kinerja Jaringan Sensor Nirkabel ... 

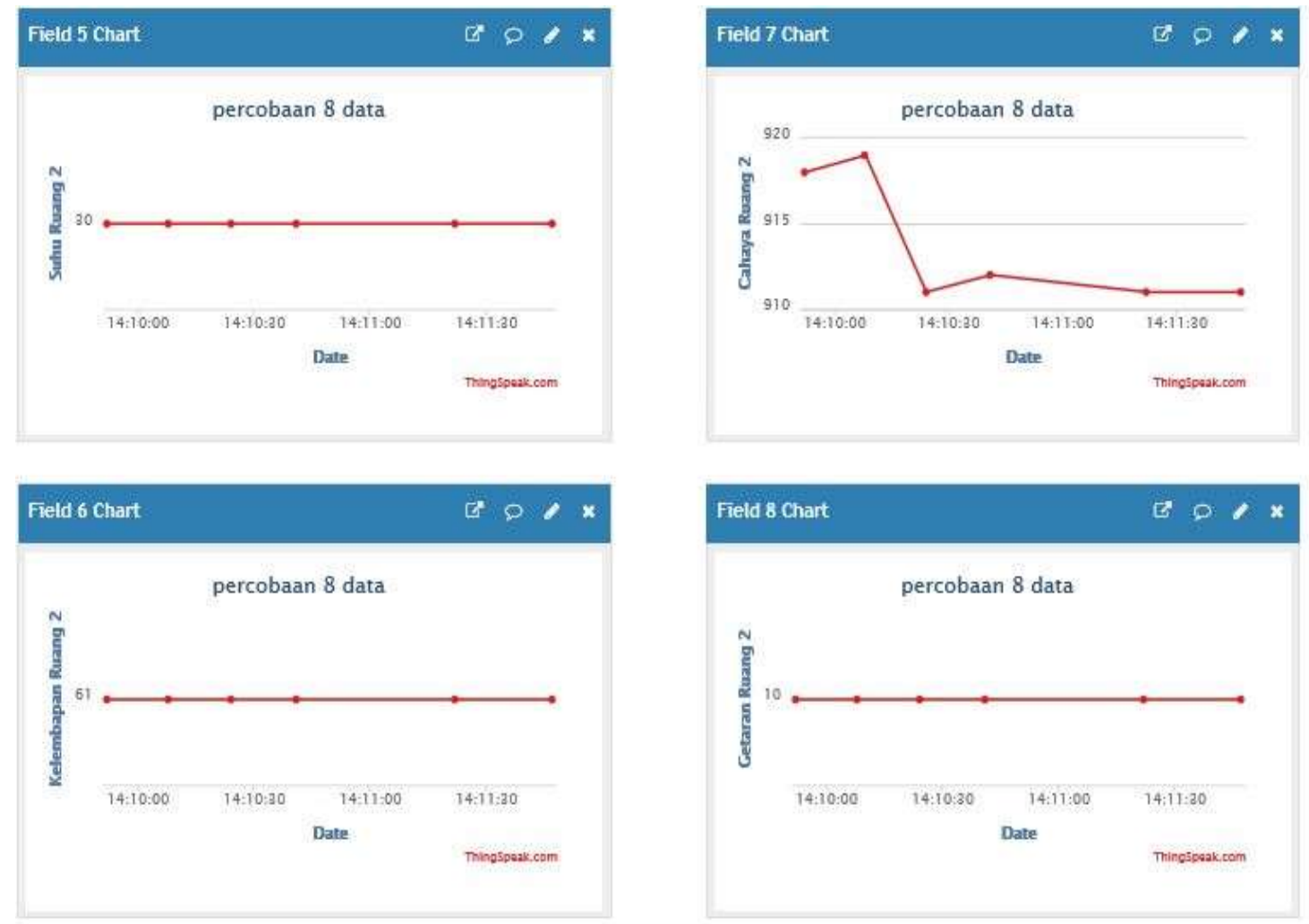

Gambar 19: Hasil Pengiriman Data Sensor ke internet field 1-8 (thingspeak.com)

Keterangan Gambar:

Field $1=$ Data sensor Suhu ruang 1

Field 2 = Data sensor Kelembaban ruang 1

Field 3 = Data sensor Cahaya ruang 1

Field $4=$ Data sensor Getaran ruang 1

Field $5=$ Data sensor Suhu ruang 2

Field $6=$ Data sensor Kelembaban ruang 2

Field $7=$ Data sensor Cahaya ruang 2

Field $8=$ Data sensor Getaran ruang 2

Gambar 19: adalah hasil data yang sudah dikirimkan dari node sensor ke internet. Syarat utama agar dapat mengirim data ke Web yaitu harus memiliki channel dan ApiKey yang sudah didaftarkan

\section{KESIMPULAN}

Berdasarkan hasil penelitian pengujian prototipe ini, diperoleh hasil secara umum bahwa kinerja pada jaringannya bekerja dengan baik pada lingkungan indoor maupun outdoor. Namun pada kondisi indoor hanya terkendala pada luas ruangan pada pengujian. Dari sisi pengujian konsumsi energi, yang digunakan pada prototipe sangatlah kecil pada seluruh proses pengiriman data sensor dari mode offline ataupun mode online, yaitu 0.32 Watt sampai dengan 0.64 Watt dalam waktu 10 menit. Sehingga durasi waktu total jika prototipe digunakan secara terus menerus secara real-time hingga batas tegangan 7 Volt, dengan jarak diubah - ubah adalah 70 menit. Hasil ini menunjukkan komunikasi jaringan pada hybrid network mengonsumsi daya yang relatif rendah dengan metode clustering.

\section{REFERENSI}

[1] Yudho Yudhanto. 2019. IOT Internet of Things. [Online] (Updated 23 December 2015) Tersedia di: http://rumahstudio.com. [Accessed 13 December 2020].

[2] Muafani. 2020. Pemanfaatan Internet of Think (IoT) pada Desain Rumah Tinggal, Jurnal Ilmiah Arsitektur. Vol. 10, No. 2, Pp. 66-61.

[3] Luis, Huriviades, M., 2021. Towards a Service-Oriented Architecture for the Energy Efficiency of Buildings: A Systematic Review. Department of Computer Science, University of Alcala, 28801 Alcala de Henares, Spain, The IEEE Internet of Things Journal.

[4] B. Usmanto, T. Susilowati. Perancangan Prototype Teknologi Smart Building Menggunakan Arduino Berbasis Web Server untuk Mendukung Pembangunan Provinsi Lampung Menuju Program Lampung "Smart City". Jurnal Manajemen Sistem Informasi dan Teknologi. Vol. 07, No. 02, Pp 57-65, Des 2017.

[5] D. I Pujiana, A. S. Handayani, Aryanti. Perancangan Wireless Sensor Network Dalam Sistem Monitoring Lingkungan. Computer Science and ICT. Vol. 3 No. 1, Pp 119-202, 2017.

[6] S. P Anggara, A. A. N. Amrita, D. C. Khrisne, 2018. Rancang Bangun Alat Kontrol dan Monitoring Konsumsi Listrik Lampu Penerangan Jalan Umum Berbasis Mikrokontroler ATMega 2560. Majalah Ilmiah Teknologi Elektro, Vol. 17, No. 3, Pp 427-432, September - Desember 2018.

[7] N. C. Utomo, R. Primananda, R. A. Siregar. Analisis Pemakaian Energi Pada Sensor Node Dengan Protokol Komunikasi Zigbee Menggunakan Solar Cell. Jurnal Pengembangan Teknologi Informasi dan Ilmu Komputer, Vol. 2, No. 9, September 2018, hlm. 3006-3012.

[8] Neil, S.L., 2017. Energy Audit and Analysis of the Electricity Consumption of an Educational Building in the Philippines for smart consumption. Mechanical Engineering Department, De La Salle University, 2401 Taft Avenue, Manila, Philippines 0922. IEEE Journal 2017. 
Majalah Ilmiah Teknologi Elektro, Vol. 20, No.2, Juli-Desember 2021

DOI: https://doi.org/10.24843/MITE.2021.v20i02.P05

[9] W. Wiyardani, H. Mistialustina. Aplikasi Penampil Data Hasil Monitoring

Suhu dan Kelembaban Ruangan pada Wireless Sensor Network. Jurnal Infotronik Volume 5 No. 1, Pp 22-36, Juni 2020.

[10]S. S. Anjani, L. Jasa, R. Agung. Rancang Bangun Sistem Minimarket Otomatis Berbasis IoT. Majalah Ilmiah Teknologi Elektro, Vol. 19, No. 2, Pp 255-262 Juli - Desember 2020.

[11] Sastra, I. M. D., Sastra, N. P., \& Wiharta, D. M. 2017. Prototype Smart Building Data Center berbasis Jaringan Sensor Nirkabel. Prosiding SNATIA tanggal 28 Juli 2017 di Universitas Udayana kampus Bukit Jimbaran, Badung, Bali. ISSN: 2302-450X, Pp 538-544.

[12]I. Gunawan, T. Akbar, M. G. Ilham. Prototipe Penerapan Internet of Things (Iot) Pada Monitoring Level Air Tandon Menggunakan Nodemcu Esp8266 Dan Blynk. Infotek. Jurnal Informatika dan Teknologi Vol. 3 No. 1, Januari 2020, Pp $1-7$.

[13] Choudhury, N., Matam, R., Mukherjee, M. A Performance-to-Cost Analysis of IEEE 802.15.4 MAC With 802.15.4e MAC Modes, Department of Computer Science and Engineering, IIIT Guwahati, Guwahati 781015, India, March 11, 2020 Pp 41936-41950.

[14] Wadarman, J.T., Sastra, N. P., \& Wiharta, D. M. 2017. Hybrid Network untuk Pengembangan Internet of Things. Prosiding SNATIA tanggal 28 Juli 2017 di Universitas Udayana kampus Bukit Jimbaran, Badung, Bali. ISSN: 2302-450X, Pp 488-494.

[15]R. A. Hidayatullah, Z. Sari, M. Faiqurahman. Implementasi Pull Message dengan menggunakan Restful Web Service pada komunikasi Wireless Sensor. Jurnal Ilmiah Teknologi Sistem Informasi. 2018, Pp 65-74.

[16] R. Z. Alhamri, A. F. Dianta, T. A. Cinderatama .Kinerja Teknologi ZigBee pada Wireless Sensor Networks untuk Sistem Pengurasan Kolam Ikan Air Tawar. Jurnal INOVTEK POLBENG - SERI INFORMATIKA, Vol. 4, No. 2, Pp 132-146, 2019.

[17]R. N. Ifansyah, N. Hidayat, A. A. Soebroto. Implementasi Wireless Sensor Network untuk Monitoring Limbah Cair Gondorukem Menggunakan Modul Wifi Esp8266. Jurnal Pengembangan Teknologi Informasi dan Ilmu Komputer, Vol. 5, No. 6, Juni 2021, Pp 2098-2107.

[18]“XBee ${ }^{\circledR} \&$ XBee-PRO ${ }^{\circledR}$ 802.15.4 OEM RF Modules Data Sheet". Digi International Inc.

[19] “XBee ${ }^{\mathbb{R}} / \mathrm{XBee}-\mathrm{PRO}{ }^{\mathbb{R}}$ RFModules Data Sheet”. Digi International Inc.

[20] “Arduino Mega 2560 Data Sheet". The producer of Arduino, Costa Rica's forest's.

[21] "WiFi Modem ESP8266 Data Sheet". Shenzhen Anxinke Technology CO; LTD.

[22]Fathur, Z., 2018. Kinerja Jaringan Nirkabel ZigBee Pada Smart Home Dalam Monitoring Perangkat Ruang. Jurusan Teknik Elektronika

[23]S. Ikhwan, R. F. Christianti, N. Ardilla, Suryadi. Analisis Quality Of Service Jaringan Mobile Wiseland Menggunakan DIGI-XCTU. Jurnal Nasional Teknologi dan Sisitem Informasi - Vol. 06 No. 01, 2020, Pp 046054.

I Made Sastra Dwikiarta: Kinerja Jaringan Sensor Nirkabel ... 
\{ Halaman ini sengaja di kosongkan\} 